\title{
DESAIN SAMPUL MAJALAH SEBAGAI UJUNG TOMBAK PEMASARAN
}

\author{
Lintang Widyokusumo \\ Jurusan Desain Komunikasi Visual, School of Design, BINUS University \\ Jln. K.H. Syahdan No. 9, Kemanggisan, Jakarta Barat 11480 \\ lintangw@binus.edu
}

\begin{abstract}
Amid the proliferation of electronic media competition, the role of conventional media such as magazines still becomes a promising choice. The recency of printing techniques, finishing and layout software currently enable more rapid publication of a magazine. Its presence in every corner of the city increasingly makes it easier for consumers to buy and makes it a complete source of information plus attractive bonus which is always a tempting offer in each issue. Amid the hundreds of magazine design magazine rack is on store / stall / supermarket sales how can a magazine survive? Surely, the role of creativity of magazine cover designs as a bridge of communication to the customers becomes the forefront of marketing which is highly important.
\end{abstract}

Keywords: magazine cover, creativity, marketing

\begin{abstract}
ABSTRAK
Di tengah maraknya persaingan media elektronik saat ini, peran media konvensional seperti majalah masih menjadi pilihan media yang menjanjikan. Kemutakhiran teknik cetak, finishing serta piranti lunak tata letak saat ini makin memungkinkan cepatnya penerbitan suatu majalah. Kehadirannya disetiap sudut kota makin memudahkan konsumen untuk membeli dan menjadikannya sumber informasi yang lengkap ditambah bonus menarik yang selalu menjadi tawaran menggiurkan disetiap edisi. Di tengah ratusan desain majalah yang ada pada rak majalah toko/lapak/supermarket bagaimana penjualan sebuah majalah dapat bertahan? Tentunya peran kreativitas desain sampul majalah sebagai jembatan komunikasi kepada pelanggan menjadi ujung tombak pemasaran yang sangat penting.
\end{abstract}

Kata kunci: magazine cover, kreativitas, pemasaran 


\section{PENDAHULUAN}

Di tengah maraknya persaingan media yang mengedepankan teknologi mutakhir namun tidak dapat disangkal bahwa kehadiran media majalah masih menjadi pilihan masyarakat untuk tetap update mendapatkan informasi dengan menawarkan tampilan sampul muka yang eye catching, permainan warna, teknik cetak dan permainan tipografi yang menawan.

Euphoria kebebasan pers pada awal tahun 2000 menjadi pemicu maraknya industri majalah di tanah air. TIdak mengherankan jika jumlah penerbitan melonjak drastis dari berjumlah ratusan menjadi ribuan. Untuk menyiasati hal tersebut penerbit ditantang untuk lebih kreatif dalam memenangkan pangsa pasar yang semakin kompetitif. Secara provinsi, pasar memang masih berpusat di Jakarta dengan 83\% mendominasi dari total penerbitan majalah skala nasional (Direktori Pers Indonesia). Segmenntasi dan fokus adalah salah satu kiat untuk tetap bertahan dalam industri ini.

Kekuatan sebuah majalah tidak lepas dari desain sampul majalah yang menjadi ujung tombak komunikasi awal kepada konsumen yang dituju. Mungkin terkesan sangat mudah dan sederhana dalam mendesain sebuah cover majalah, terlihat seperti hanya meletakkan sebuah foto/image ataupun ilustrasi kemudian meletakkan beberapa tulisan di atasnya. Namun dalam perancangannya, sebuah cover majalah tidak hanya membutuhkan sebuah kreativitas, namun juga keahlian secara teknis.

Titik perhatian pertama sebuah majalah adalah dari sebuah covernya yang menarik perhatian. Perjalanan sebuah majalah tidak hanya terhenti ketika majalah tersebut selesai dicetak. Penentuan apakah desain majalah itu menarik atau tidak untuk dibeli adalah ketika desain majalah tersebut (terutama cover) bersanding dengan kompetitor di rak-rak lapak majalah maupun toko buku. Saat ini begitu banyak pilihan majalah yang tidak hanya diterbitkan oleh penerbit lokal namun juga majalah impor yang dapat kita jumpai.

\section{METODE PENELITIAN}

Artikel disusun berdasarkan studi pustaka yaitu menyeleksi beberapa sumber referensi baik tercetak maupun elektronik dan beberapa observasi pada beberapa cover majalah yang beredar, kemudian informasi tersebut dirangkum menjadi dasar penulisan artikel ini.

\section{HASIL DAN PEMBAHASAN}

Majalah mulai diperkenalkan di Inggris sekitar tahun Di pertengahan tahun 1700, sebuah cover majalah tidak terlihat seperti pada saat ini. Isi dari majalah lebih kepada tulisan mengenai politik, biografi dan kritik. Pada saat majalah pertama menggunakan cover, fungsinya tidak lebih seperti sebuah cover buku dimana hanya ada judul dan juga data-data publikasi namun tidak memberikan informasi artikel apa saja yang akan kita temui dalam edisi saat itu.

Desain cover tersebut berlangsung hingga tahun 1800, setelah itu cover majalah mulai mencantumkan judul-judul artikel yang akan ditemui diedisi tersebut lengkap dengan ikon setiap departemennya (musik, seni, literatur, sains dll.) dan menggunakan logo (masthead). Penulisan artikelpun sudah mulai dengan isu-isu umum. 
Di awal tahun 1900an isi majalah berkembang menjadi artikel investigasi, skandal dan korupsi. Selanjutnya semakin berkembang menjadi lebih spesifik mengangkat isu-isu gaya hidup. Di Indonésia sendiri perkembangan penerbitan majalah berkembang setelah kemerdekaan Indonésia tahun 1945. Isi artikel ditujukan untuk mengobarkan semangat perlawanan terhadap sisa-sisa penjajahan Belanda untuk kesatuan dan persatuan bangsa.

Setelah era orde baru kebebasan pers semakin memicu berkembang pesatnya industri majalah. Majalah-majalah saat ini semakin fokus dan segmentasi pasar yang spesifik. Kecanggihan teknologi percetakan dan software desain memudahkan proses editing dan lay-out. Saat ini keberadaan majalah lokal harus gigih bersaing dengan majalah impor maupun majalah dengan sistem waralaba, yaitu terjemahan dalam bahasa Indonésia dimana konten artikel diadaptasi dari luar negeri dipadu dengan konten lokal.

Frekuensi penerbitan majalah biasanya beragam dari majalah mingguan, dwi mingguan, bulanan bahkan tiga bulan sekali. Secara umum ukuran majalah adalah 8.5 x 11 inch, dimana ukuran tersebut tergantung kepada konsep majalah dan bahkan biaya pencetakan. Dari semua anatomi yang terdapat dalam majalah, desain sampul menempati urutan teratas sebagai daya tarik utama sebuah majalah. Kekuatannya dapat membuat perhatian konsumen terhenti beberapa saat untuk mengamati, membaca dan bahkan berakhir dengan memutuskan untuk membelinya.

\section{Anatomi Sebuah Desain Sampul Majalah}

Sebelum kita mengenal sebuah sampul majalah desain yang baik, ada baiknya kita memahami anatomi dari desain sampul majalah. Gambar 1 adalah anatomi sampul sebuah majalah.

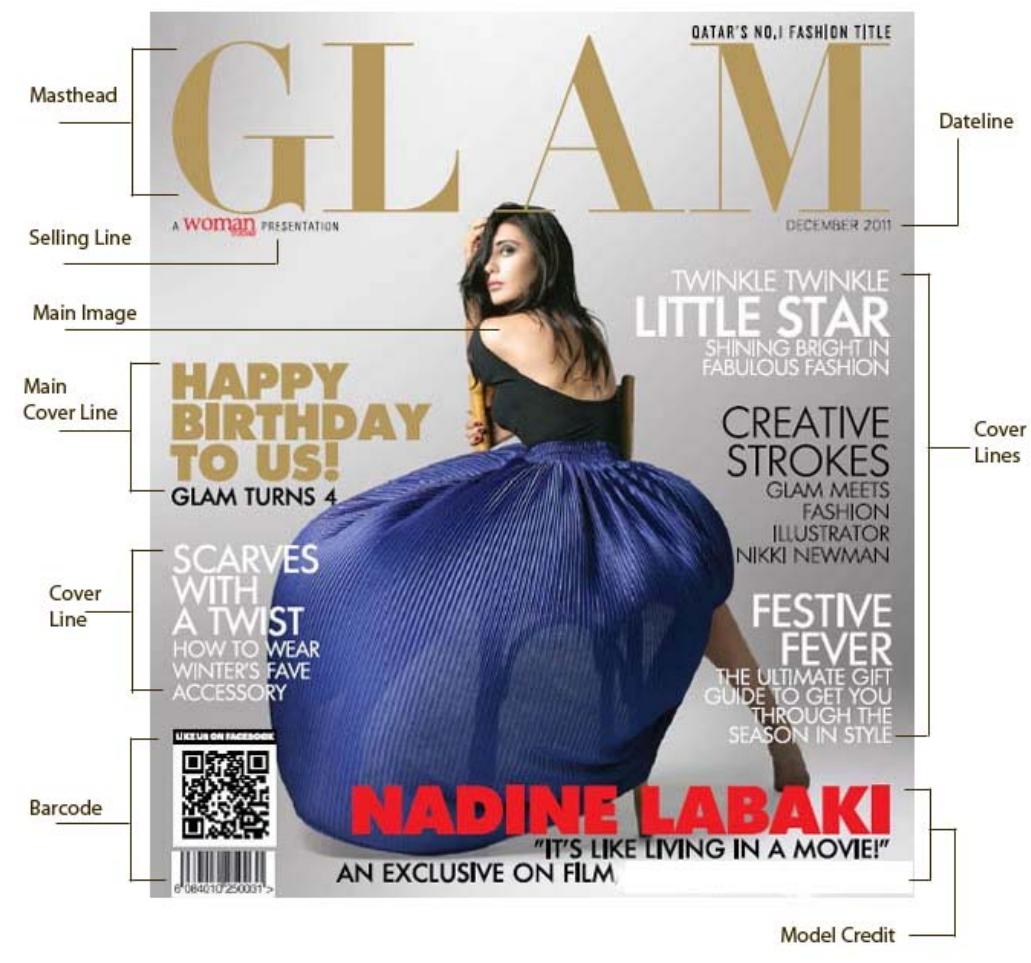

Gambar 1 Anatomi Sampul Sebuah Majalah 
Masthead/Nameplate adalah logo dari majalah tersebut yang membawa identitas dari majalah tersebut. Masthead biasanya terdiri dari desain sebuah kata dari nama majalah tersebut dengan pilihan karakter tipografi (yang dimodifikasi), warna, komposisi yang disesuaikan dengan konsep dari majalah tersebut. Perencanaan peletakan masthead sesuai standar adalah pada bagian atas dari cover majalah, hal tersebut untuk membantu terbacanya masthead ketika berjajar bersama kompetitor lain pada rak majalah di kios maupun toko buku.

Main Cover Line adalah artikel utama yang menjadi cerita sampul dari setiap edisi sebuah majalah. Judul artikel yang profokatif membantu daya tarik sebuah cover majalah. Pilihan kalimat yang pendek dan permainan kata kreatif adalah solusi terbaik. Cover line yang baik dapat mewakilkan sebuah visual yang menarik serta menjanjikan artikel menarik di dalamnya.

Cover Line adalah judul beberapa artikel lain yang paling menarik pada edisi majalah tersebut hasil seleksi dari beberapa artikel yang diterbitkan.

Image cover adalah ujung tombak daya tarik sebuah majalah. Visual yang ditampilkan sebagai image cover dapat berupa fotografi, ilustrasi dan tipografi.

\section{Merancang Sebuah Sampul Majalah Ideal}

Ketika kita ditantang untuk mendesain sebuah sampul majalah, maka kita dituntut untuk menciptakan sebuah kekuatan kreativitas dan komposisi. Sebuah desain sampul majalah dapat berupa fotografi, tipografi (desain huruf), gambar ilustrasi atau bahkan gabungan dari semua elemen tersebut.

Desain harus spesifik disesuaikan dengan konsep majalah tersebut sehingga target market dapat langsung mengenalnya, tertarik dan kemudian membelinya. Maka ketika kita ingin mendesain sebuah sampul majalah hal-hal yang perlu diperhatikan adalah:

Menarik perhatian. Majalah biasa didistribusikan di took buku, supermarket, lapak majalah atau bahkan loper koran \& majalah. Desain sampul majalah harus dapat merebut perhatian pada pandangan pertama dengan penataan cover line yang terbaca jelas, kontras yang baik, dipadukan dengan imej foto/ilustrasi yang baik sehingga terbaca dari kejauhan.

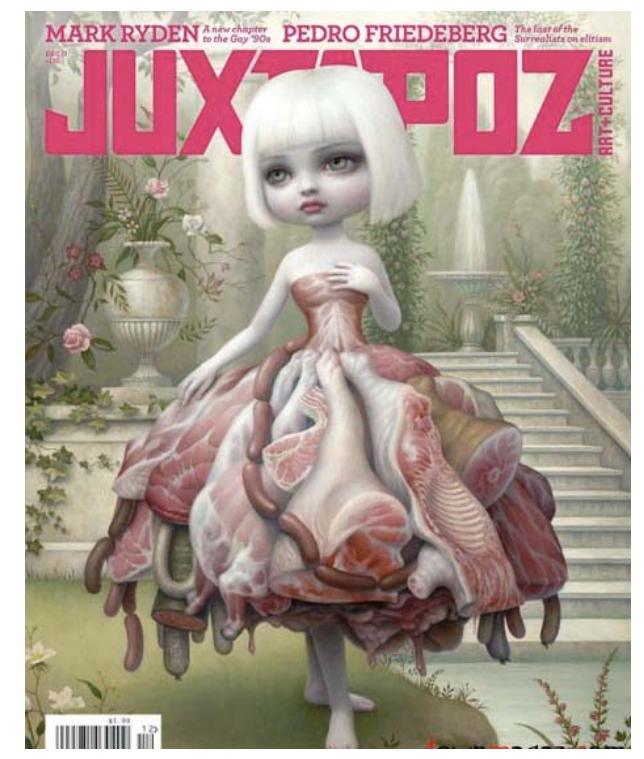

Gambar 2 Contoh Cover Majalah yang Menarik Perhatian 
Mengungkapkan cerita. Setiap pembaca harus dapat melihat judul menarik dari kisah cerita yang ingin dijual pada edisi tersebut. Menekankan judul kisah utama dan judul-judul artikel menarik lainnya akan menambah daya tarik sebuah majalah.

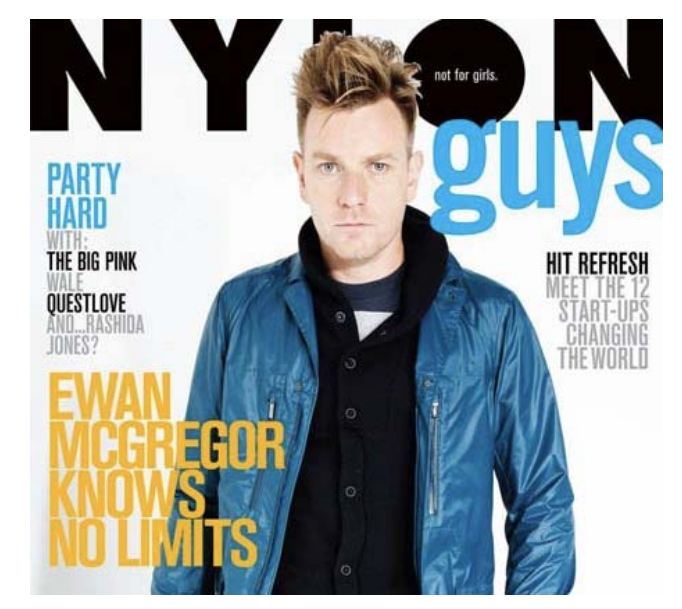

Gambar 3 Cover Majalah dengan Judul Artikel

Penggunaan warna dan huruf yang atraktif. Warna mempunyai pengaruh yang sangat kuat pada desain sampul majalah. Pemilihan tepat warna yang disesuaikan dengan konsep majalah tersebut akan menimbulkan daya tarik kuat tersendiri. Pemilihan jenis huruf yang tepat juga dapat meningkatkan tampilan yang menarik, keterbacaan yang sempurna serta gaya tersendiri. Namun perlu diperhatikan hirarki keterbacaan dari semua teks yang ada pada sampul muka. Tentunya Masthead/logo majalah harus tetap mendapat prioritas yang utama. Penggunaan jenis huruf untuk masthead hendaknya menggunakan jenis huruf yang berkarakter kuat (sesuai konsep majalah) dan jelas.

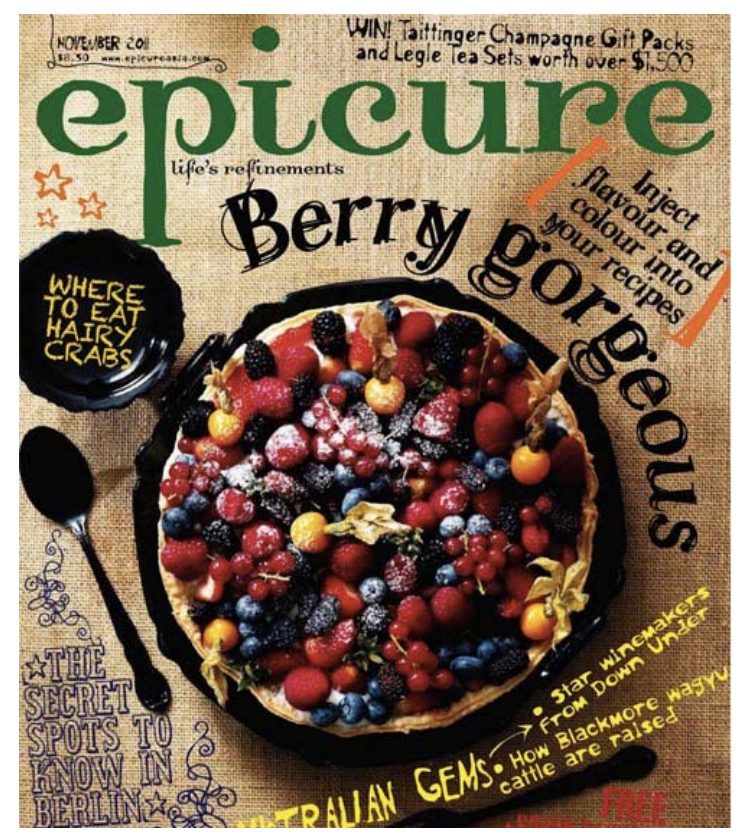

Gambar 3 Cover Majalah dengan Warna dan Huruf Atraktif 
Jelasnya identifikasi produk. Ketika merancang desain sampul majalah, pusat perhatian terletak pada imej foto/ilustrasi model/produk yang akan dijual. Dalam sekilas pandang, konsumen dapat langsung menangkap jenis majalah yang kita usung, produk utama yang ingin dijagokan dalam promosi edisi kali ini.

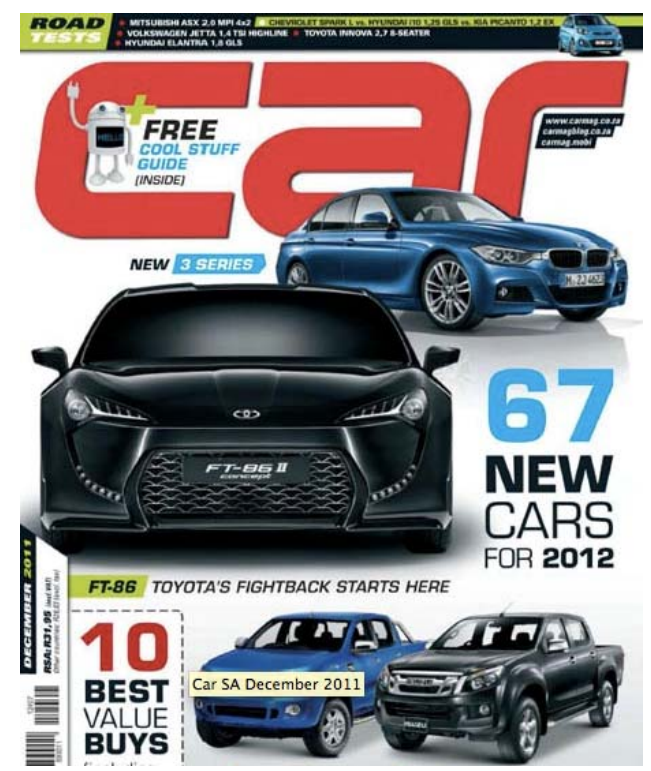

Gambar 4 Cover Majalah dengan Identifikasi Produk

Menawarkan berbagai keuntungan pada pembaca. Kita dapat melakukan berbagai penawaran menarik melalui cover lines. Tawarkan hal-hal seru dan menarik apabila konsumen membeli terbitan kali ini. Hal tersebut dapat berupa tips menarik, pengetahuan baru, voucher, dan lain-lain. Sehingga akan menjadikan edisi kali ini merupakan edisi seru yang amat sayang apabila dilewatkan.

Cover Lines yang spesifik. Gunakan kalimat yang spesifik dalam penciptaan kalimat pada cover lines. Sebagai contoh, pencantuman jumlah tips atau hal-hal yang sifatnya cuma-cuma seperti; "Dapatkan 45 tips menjadi wirausaha" atau "Gratis 10 tiket ke DUFAN". Berikan dampak yang enerjik. Gunakan kalimat yang meyakinkan konsumen bahwa mereka bisa melakukan hal-hal yang ditawarkan oleh majalah tersebut (bukan suatu mimpi atau menggurui). Seperti "Dandan sendiri ala Dian Sastro" atau "Beternak ikan Koi di halaman”

Etalase produk. Apapun konsep dan jenis majalah, desain sampul merupakan etalase produk yang akan dijual. Majalah komputer tentu akan memasang imej komputer tercanggih keluaran terbaru, begitupun majalah flora tentu akan memasang imej jenis flora yang sedang digandrungi saat itu. Dengan konsistensi seperti ini maka para konsumen akan dengan segera mengetahui konsep dan isi dari majalah tersebut.

Identitas yang kuat. Setiap majalah mempunyai identitas yang berbeda. Tugas para desainer visual untuk merancang kekuatan konsep desain majalah yang kuat. Dengan konsep dan kekhasan yang kuat maka konsumen akan dengan cepat dapat mengenalnya di rak-rak majalah. Kekuatan identitas tidak hanya dari masthead yang unik namun juga dari keseluruhan desain sampul, pemilihan tipografi, warna serta penulisan naskah yang jitu. 


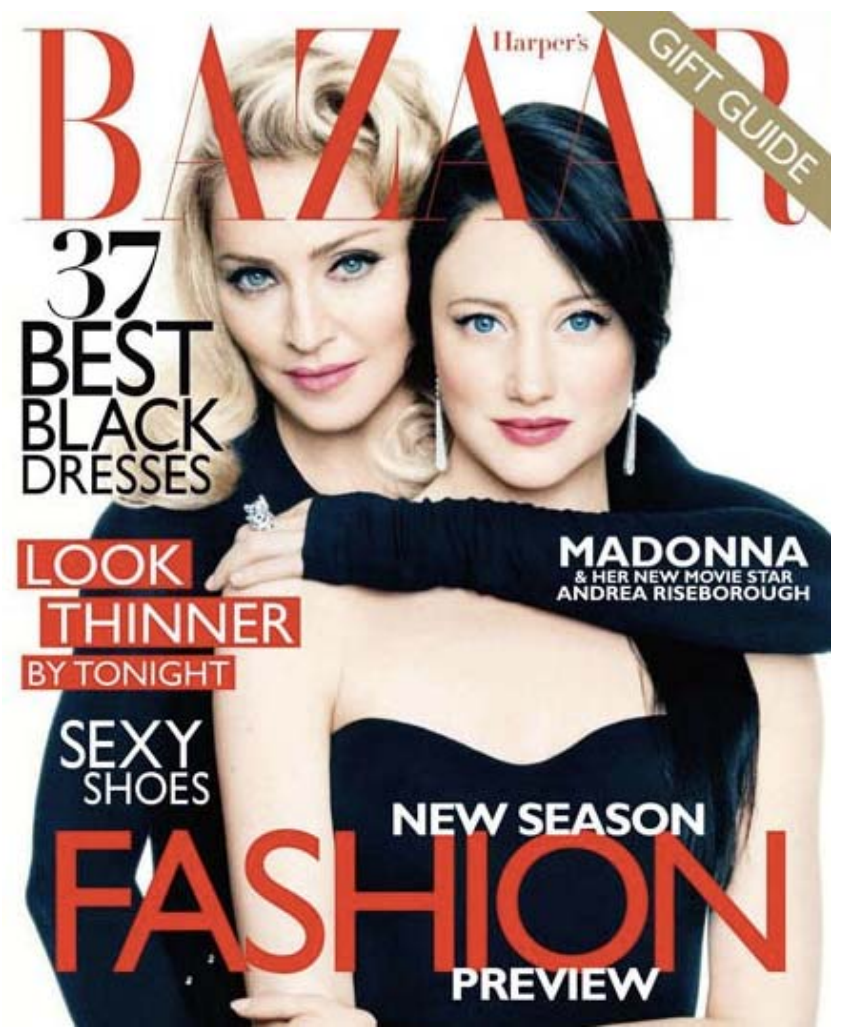

Gambar 5 Majalah dengan Penawaran Menarik dalam Cover Lines

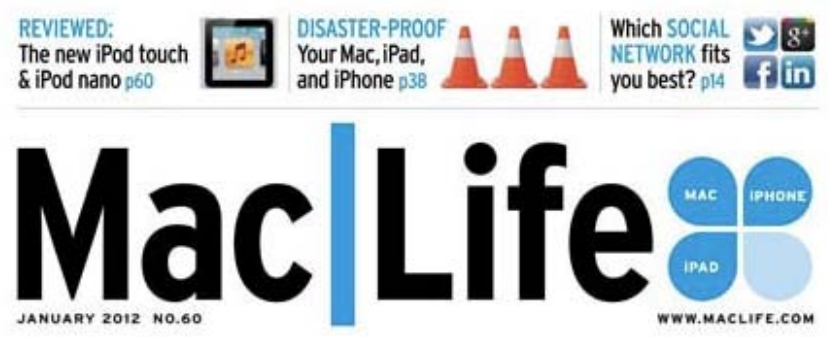

\section{iPHONE 4S SUPERTEST}

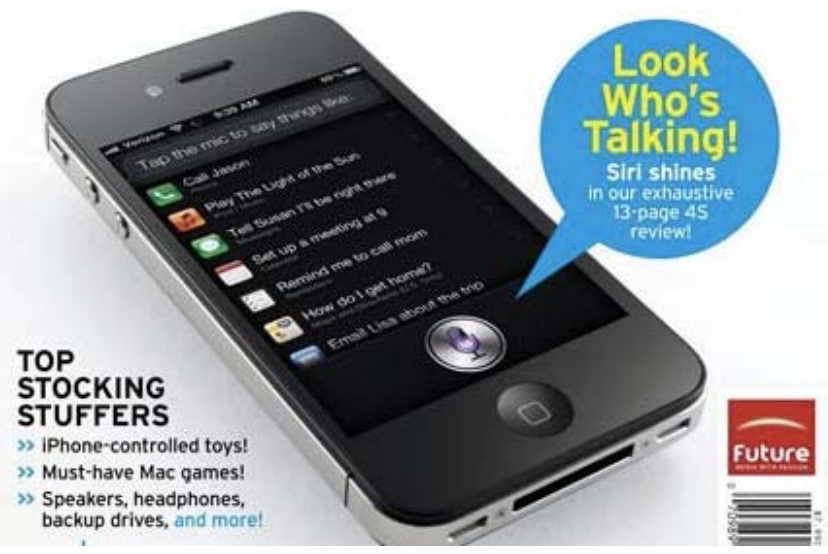

Gambar 6 Cover Majalah dengan Presentasi Produk 


\section{SIMPULAN}

Kehadiran majalah sebagai pilihan masyarakat sebagai media informasi seperti tak lekang oleh jaman. Walaupun majalah berkembang sejak tahun 1700an namun kehadirannya tetap dinantikan. Sensasi kita untuk menyentuh, aroma kertas serta stimulasi indera peraba pada media konvensional seperti majalah memang tidak tergantikan oleh gadget elektronik saat ini. Bahkan banyak konsumen membelinya untuk tujuan koleksi dan clipping informasi yang dibutuhkannya. Memang usia edar majalah boleh dibilang adalah panjang karena dapat disimpan menjadi referensi ditambah teknologi cetak yang makin modern menawarkan kertas bermutu dengan hasil kualitas cetak fotografi yang menawan. Bahkan saat ini majalah dapat digunakan sebagai sarana promosi produk untuk pemberian kupon, sampel produk serta bonus produk lainnya. Khususnya di Indonesia pertumbuhan ekonomi, kebebasan pers dan keterbukaan membawa semangat industri pers khususnya majalah untuk berlomba-lomba menjual informasi yang menarik serta menguasai pasar dengan menjual segmentasi. Sekali lagi semua konten menarik sebuah majalah dapat terkomunikasikan dalam satu halaman sampul majalah. Disinilah kreativitas desain sampul majalah dapat teruji, perpaduan antara logo majalah, fotografi/ilustrasi, judul artikel, warna, bonus dan apapun itu harus dapat tersampaikan dengan baik kepada konsumen.

\section{DAFTAR PUSTAKA}

Goodman, A. (2007). 7 essentials of graphic design: How design book. Cincinnati, Ohio.

Samara, T. (2002). Making and Breaking the Grid. Glouchester, MA: Rockport.

Tselentis, J. (2011). Type, Form and Function. Beverly, Massachusettes: Rockport. 